\title{
SINGLE-STATION POLARIZATION ANALYSIS ACCORDING TO THE ZAGATALA EARTHQUAKE ON MAY 7, 2012
}

\author{
Kazimova S.E. \\ Republican Seismological Survey Center of National Academy of Sciences of Azerbaijan \\ 123, H.Javid pr., Baku, Az 1143: sabina.k@mail.ru
}

Keywords: polarization of shear $S H$ and $S V$ waves, Lissajous figures, incident angle and azimuth of the seismic waves
Summary. The article presents an analysis of the parameters of split shear waves from a surface $(\mathrm{h}=8 \mathrm{~km})$ earthquake that occurred within the Great Caucasus in Zagatala region on May 7 , 2012 with $\mathrm{ml}=5.6$. Spatial analysis of waveforms is carried out using 3-component digital signal recordings. For selected sections of the 3-component recording in the DIMAS program, a threedimensional graph of the particle motion path and the projection of the motion path on the NE, NZ, EZ planes is constructed. The birefringence effect, i.e. the shear wave is split into two $\left(S_{1}\right.$ and $\mathrm{S}_{2}$ ), each of which has its own polarization and speed for broadband three-component records (HHE, HHN, HHZ) of one seismic station ZKT. This made it possible to study small-scale strains for a better understanding of the dynamic processes and properties chances of the medium with depth. At the same time, the dependence of the parameters of split $\mathrm{S}$ waves on the direction of propagation and spatial heterogeneity of the physical properties of the medium requires a more detailed analysis of the data in space and time. It was established that the fast and slow S-waves are well distinguished in the wave field, their polarization vectors are mutually orthogonal. Subsequent waves have much smaller amplitudes, and their azimuths are close to the azimuth of the slow wave $\mathrm{S}_{2}$. The delay time between the first and second phases of the shear wave for the ZKT station is 3 seconds with the orientation of the polarization vectors along the azimuths $140^{\circ}$ and $70^{\circ}$.

(C) 2020 Earth Science Division, Azerbaijan National Academy of Sciences. All rights reserved.

\section{Introduction}

The polarization properties of seismic wavefields recorded by triaxial (three-component) stations can be exploited for event detection, seismic direction finding, and wavefield filtering. Development of the method of shear and converted waves, creation of the basics of multi-wave seismic exploration make it possible to obtain more complete information about the medium, including anisotropy.As is known, according to the registration of longitudinal waves, it is not always possible to distinguish easily effects associated with heterogeneity and anisotropy of elastic properties, and a very detailed observation system is required for reliable detection of anisotropy. From the data of multicomponent observations, one can obtain both kinematic and dynamic characteristics of all types of waves associated with the anisotropy of the medium. Of the dynamic characteristics, the polarization parameters of transverse and converted waves are most important for determining anisotropy. In an anisotropic medium, two shear waves with different polarization and different velocities can propagate along an arbitrary direction. One of them is called fast (S1), and the other - slow (S2). When an anisotropic S-wave layer with arbitrary polarization is incident on the boundary, S-waves split, which is a sign of the presence of anisotropy, i.e., birefringence. Polarization analysis of shear and converted waves makes it possible to separate the waves S1 and S2 in the case of their interference and to determine their polarization parameters associated with the characteristics of the anisotropic medium (Гальперин, 1977).

For the first time the idea of the widespread use of wave polarization to increase the effectiveness of seismic and seismological studies was put forward in the 1950 s by G.A. Gamburtsov. He proposed and developed a new type of wave correlation - azimuthal phase correlation, based on tracking the phases of seismic waves as a function of orientation in space of the component oscillations at a constant position of the observation points. The development of these studies led to the creation of the azimuthal method of seismic observations (Гальперин, 1977). 
Methods have been developed for processing azimuthal seismograms and determining the polarization parameters of seismic waves. This approach to the study of anisotropy of shear waves has recently been used by professor at the University of Missouri E.Sandwoll in his studies.

Thus, the purpose of this article was to determine the direction of particle displacement of the medium and the parameters of elliptically polarized vibrations, to evaluate the accuracy of determining the direction of the particle motion vector, and to identify split shear waves using the Zagatala earthquake which occurred on May 7, 2012 with $\mathrm{ml}=5.6$.

\section{Polarization}

Wave polarization is a characteristic of shear waves that describes the behavior of a vector of an oscillating quantity in a plane perpendicular to the direction of wave propagation. Polarization cannot occur in a longitudinal wave, since the direction of oscillations in waves of this type always coincides with the direction of propagation. A transverse wave is characterized by two directions: the wave vector and the amplitude vector, which are always perpendicular to the wave vector up to the motion of space. The wave vector shows the direction of wave propagation, and the amplitude vector shows in which direction the oscillations occur. In three-dimensional space there is another degree of freedom - the possibility of rotation of the amplitude vector around the wave vector. The triple of vectors associated with each point of the biregular curve forms a Frenet frame (https://en.wikipedia.org/wiki/Polarization_waves).

There are three reasons for the polarization of waves: 1) asymmetric generation of waves in a disturbance source; 2) the anisotropy of the wave propagation medium; 3) refraction and reflection at the boundary of two media. Polarization is described by Lissajous figures (fig.1), and corresponds to the addition of transverse vibrations of equal frequency (with different phase shifts).

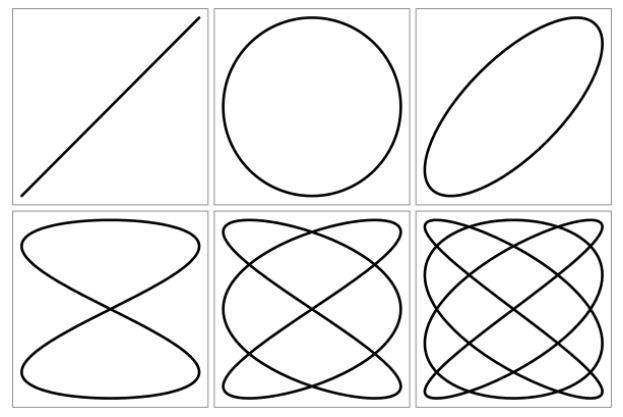

Fig. 1.The polarization described by the Lissajous figures

If the oscillation frequencies are equal, the Lissajous figures are an ellipse, the two extreme forms of which are a circle and a straight line segment. In the general case for harmonic waves, the end of the vector of an oscillating quantity describes an ellipse in the plane directed transverse to the direction of wave propagation: this is an elliptical polarization. Important particular cases are linear polarization, in which perturbation oscillations occur in one plane, in this case they speak of a "plane-polarized wave" and circular polarization, in which the end of the amplitude vector describes a circle in the plane of oscillation; circular polarization (like elliptical), depending on the direction of rotation of the vector, can be positive or right and negative or left (https://en.wikipedia.org/wiki/Polarization_waves).

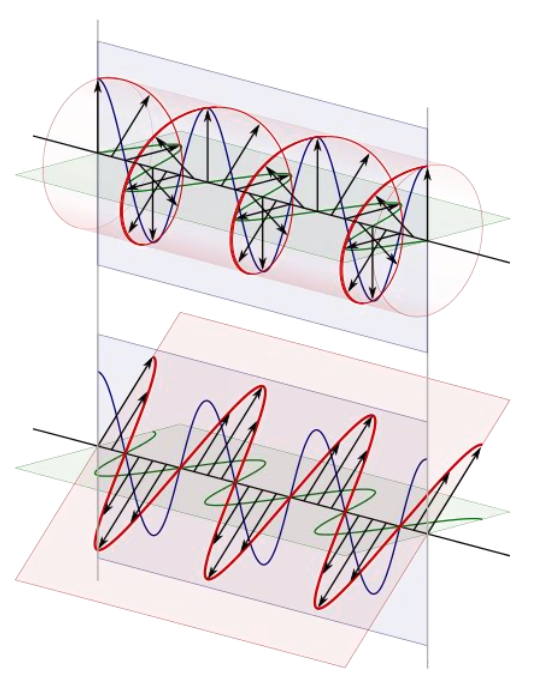

Fig. 2. The difference between circular and plane polarized waves

\section{Particle motion}

$\mathrm{P}$ and $\mathrm{S}$ waves are linearly polarized, with slight deviations in the inhomogeneous and partially anisotropic real Earth. Incontrast, surface waves may either be linearly polarized in the horizontal plane perpendicular to the direction of wave propagation (transverse polarization; $\mathrm{T}$ direction; e.g., Love waves) or elliptically polarized in the vertical plane oriented in the radial $(\mathrm{R})$ direction of wave propagation. P-wave particle motion is dominatingly back and parallel to the seismic ray, whereas S-wave motion is perpendicular to the ray direction (Етирмишли, Казимов, 2007). Accordingly, a Pwave motion can be split into two main components, one vertical ( $\mathrm{Z}$ ) andone horizontal (R) component. S waves, on the other hand, may show purely transverse motion, oscillating in the horizontal plane ( $\mathrm{SH}$; i.e., pure $\mathrm{T}$ component) or motion in the vertical propagation plane, at right angles to the ray direction (SV), or in any other combination of SH and SV. In the latter case $S$-wave particle motion has $\mathrm{Z}, \mathrm{R}$ and $\mathrm{T}$ components, with $\mathrm{SV}$ wave split into a $\mathrm{Z}$ and an $\mathrm{R}$ component. 


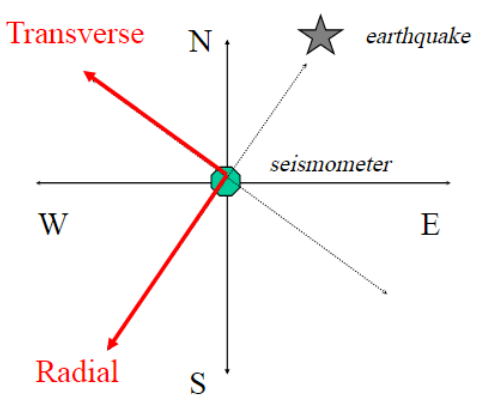

\section{Modified \\ Coordinate System \\ (1) Radial, R \\ (2) Transverse, T}

Fig. 3. Components of motion (rotation the horizontal components)

Thus, when 3-component records are available, the particle motion of seismic waves in space can be reconstructed and used for the identification of seismic wave types. However, usually the horizontal seismometers are oriented in geographic east (E) and north $(\mathrm{N})$ direction. Then, first the back azimuth of the source has to be computed and then the horizontal components have to be rotated into the horizontal $\mathrm{R}$ direction and the perpendicular $\mathrm{T}$ direction, respectively. This axis rotation is easily performed when digital 3-component data and suitable analysis software are available. It may even be carried one step further by rotating the $\mathrm{R}$ component once more into the direction of the incident seismic ray (longitudinal $\mathrm{L}$ direction). The $\mathrm{T}$ component then remains unchanged but the $\mathrm{Z}$ component is rotated into the $\mathrm{Q}$ direction of the SV component. Such a ray-oriented co-ordinate system separates and plots $\mathrm{P}, \mathrm{SH}$ and $\mathrm{SV}$ waves in 3 different components $\mathrm{L}, \mathrm{T}$ and $\mathrm{Q}$, respectively. These axes transformations are easily made given digital data from arbitrarily oriented orthogonal 3-component sensors such as the widely used triaxial sensors STS2.

\section{Description of the DIMAS program}

The DIMAS (Display, Interactive Manipulation and Analysis of Seismograms) program is designed for detailed processing and visual analysis of digital seismic signals from various acquisition systems (Дрознин, Дрознина, 2004; 2011). This program allows the user to both conduct complex processing and analysis of the seismic signal and evaluate the main parameters of earthquakes, meets the increased requirements of real-time operation on seismometric information collection systems. The "SAC" format is used as the water file. Traditional tool channel orientation:

$$
\begin{aligned}
& \text { Z-------Dip=-90, Azimuth=0 } \\
& \text { N------Dip=0, Azimuth=0 } \\
& \text { E-------Dip=0, Azimuth }=90 .
\end{aligned}
$$

Spatial analysis of waveforms is carried out using 3-component digital signal recordings. For selected sections of a 3-component recording, a three- dimensional graph of the particle motion path and the projection of the motion path on the NE, NZ, EZ plane is constructed in the program. In this case, the effect of the volumetric trajectory is created by rotation using the function keys, and projections on the corresponding planes are obtained by turning the volumetric figure at the corresponding angles. The program provides for the study of the polarization characteristics of the signal (Горшкалев и др., 2011), as well as a graphic display of the azimuths and angles of exit of the axis of polarization of the seismic wave on the Wolfe grid for a given time interval. The direction of the largest axis gives the azimuth to the source. The statistical distribution of polarization vectors in space (polarization ellipsoid) is constructed in a time window based on the covariance method. The size of the time window is generally determined within the dominant period of the wave under study (Казимова, Казимов, 2011).

As mentioned above, studies were conducted on the example of one of the most powerful earthquakes in Azerbaijan over the past 10 years - the Zagatala earthquake on May 7, 2012 with $\mathrm{ml}=5.6$. Broadband three-component records (HHE, HHN, HHZ) of one "ZKT" seismic station were selected (Fig. 4).

Fig. 5 shows azimuthal seismograms plotted in a horizontal plane with an azimuth step of $2^{\circ}$ and a count from the north in the S-wave interval, the projection of particle motion in three-dimensional space, and seismograms of a three-component recording.

When shear waves pass through an anisotropic layer, a birefringence effect occurs, i.e. the transverse wave is split into two $\left(\mathrm{S}_{1}\right.$ and $\left.\mathrm{S}_{2}\right)$, each of which has its own polarization and speed. The nonlinear polarization of the waves $\mathrm{S}$ is due to the superposition of several oscillations. In the case when the anisotropy is caused by directional fracture, the displacement vector of the wave S1 is parallel to the plane of the cracks, and by determining its polarization we are able to determine the direction of the cracks (Лунева, 2008, 2009).

Thus, for the estimation of wave parameters in the azimuthal seismograms, $S_{1}$ and $S_{2}$ phases and their following characteristics are distinguished: 1) the arrival time $\left.\mathrm{t}_{\mathrm{s} 1}, \mathrm{t}_{\mathrm{S} 2} ; 2\right)$ the time interval $\Delta \mathrm{t}_{\mathrm{s} 12}$, including both waves.

As can be seen in the figures, the fast and slow $\mathrm{S}$-waves are well distinguished in the wave field, their polarization vectors are mutually orthogonal. Subsequent waves have much smaller amplitudes, and their azimuths are close to the azimuth of the slow wave $S_{2}$. The delay time between the first and second phase of the shear wave for the ZKT station is 3 seconds with the orientation of the polarization vectors along the azimuths $140^{\circ}$ and $70^{\circ}$. 


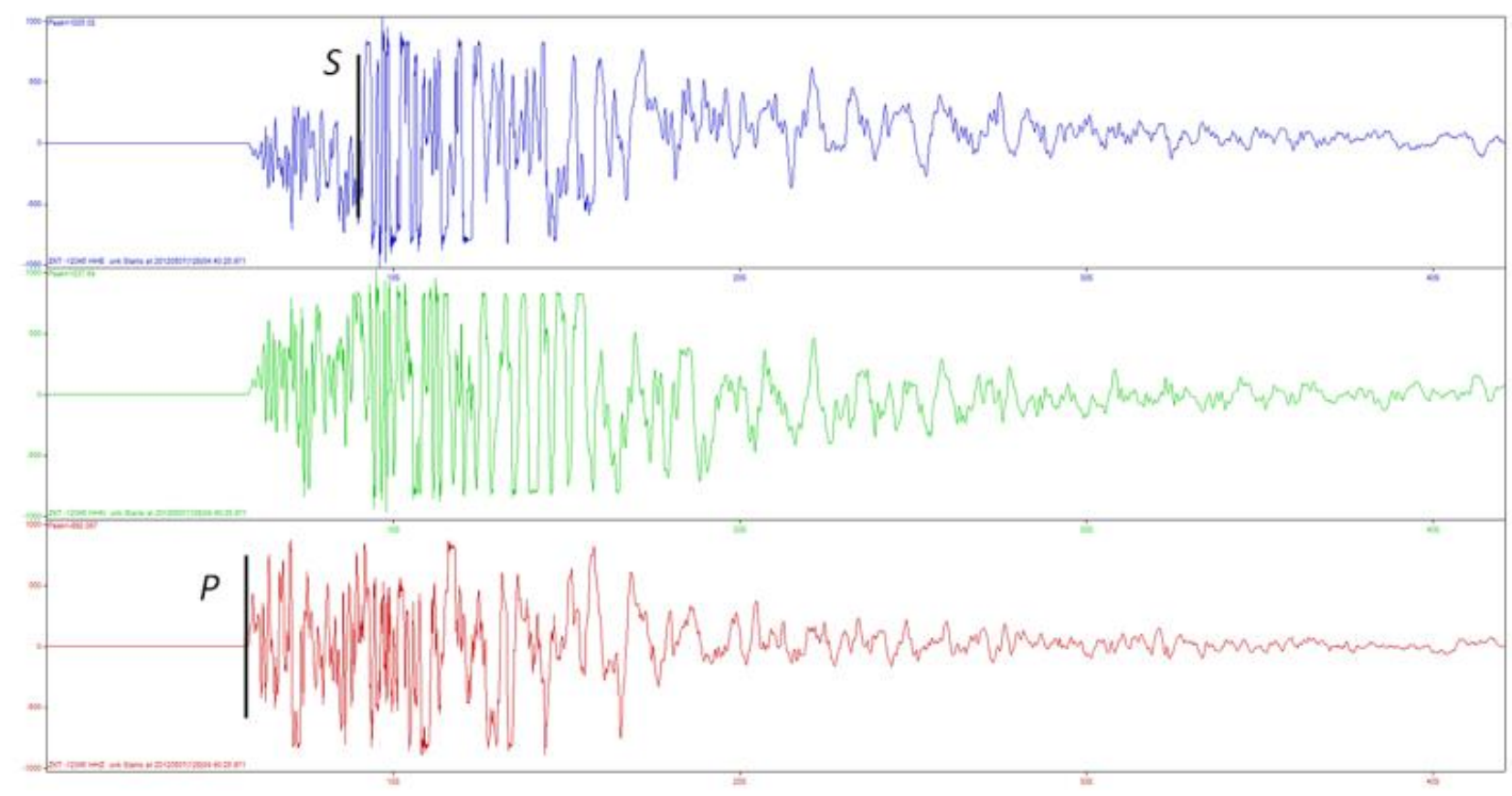

Fig. 4. Three-component recording of the Zagatala earthquake on May 7, 2012 at the "ZKT" station
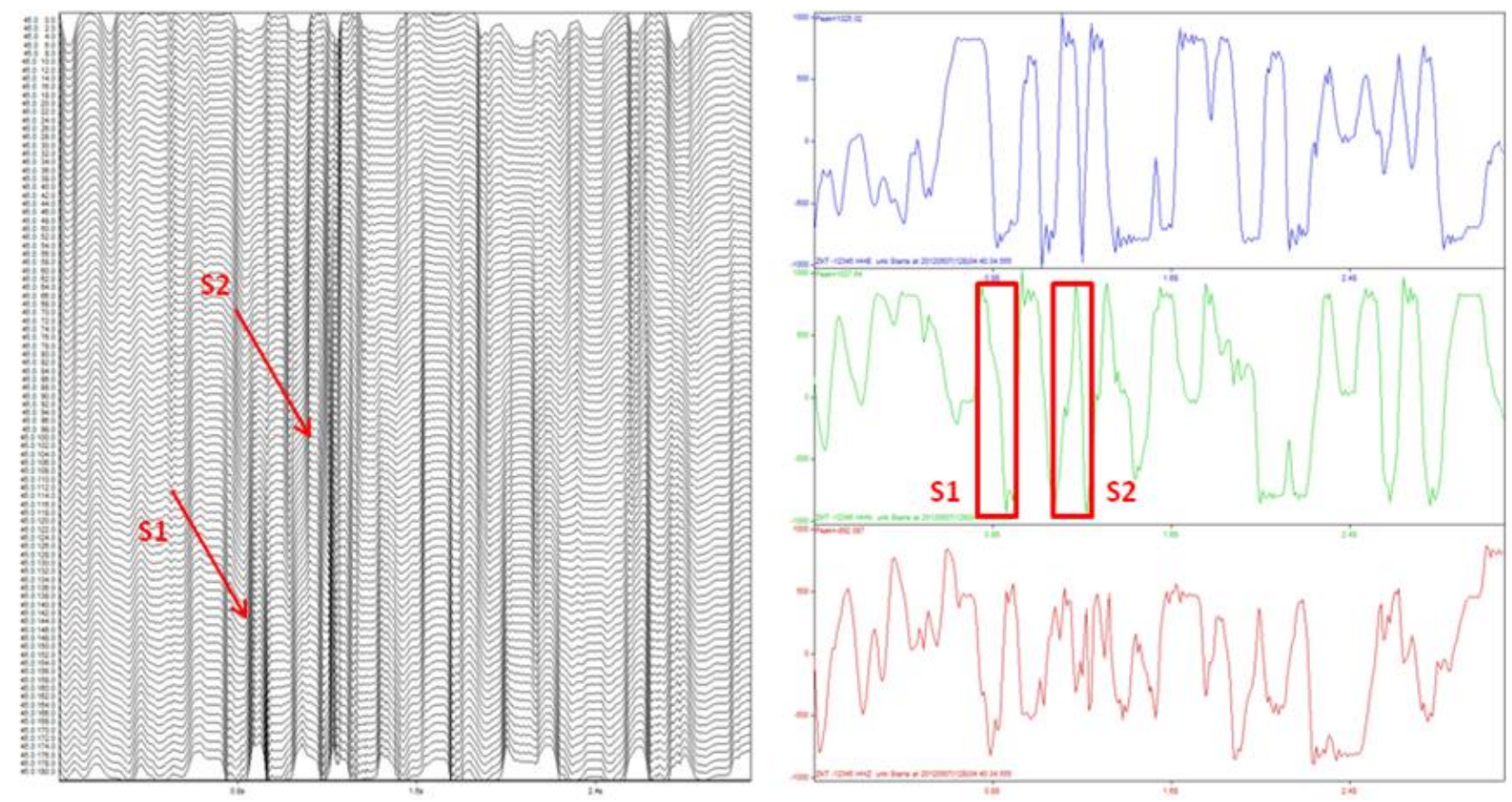

Fig. 5. An azimuthal seismogram plotted in a horizontal plane with an azimuth step of $2^{\circ}$ and a reference from the north in the S-wave interval at the Guba (QUB) station. Fast (S1) and slow (S2) waves are indicated by arrows

34 shear intervals were identified on the shear wave seismogram and particle motion trajectories were constructed in three-dimensional space with a step of one second (Fig. 6). As can be seen in the figures on the 4th second, the trajectory of particle motion in three-dimensional space changes where wave S1 appears. At the 11th second, wave S2 appears, in which the oscillations are perpendicular to each other, i.e. they oscillate in different planes. This type of trajectory changes to elliptical one. Since the displacement vector of the wave S1 is parallel to the plane of the cracks, by determining its polarization we are able to determine the direction of the cracks. Only the initial part of the recording of waves S1 is less interference, because the interfering waves, as a rule, are offset in time relative to each other (Казымова, 
Казымов, 2010, 2016). The shear wave splitting is maximum when the wave propagates parallel to the layering plane. At that moment, when the waves S1 and S2, propagating at different speeds, are displaced in time relative to each other and, interfering with each other, can form an oscillation polarized by the ellipse. The nature and parameters of the ellipse will vary depending on the conditions of the superposition of the waves. This phenomenon is clearly manifested at 25-30 time intervals where the elliptical polarization is oriented in the NE direction, and at 33-34 time intervals the oscillations polarized along the ellipse have the NW direction. At 35-36 time intervals polarization fluctuations take the form of a circle.
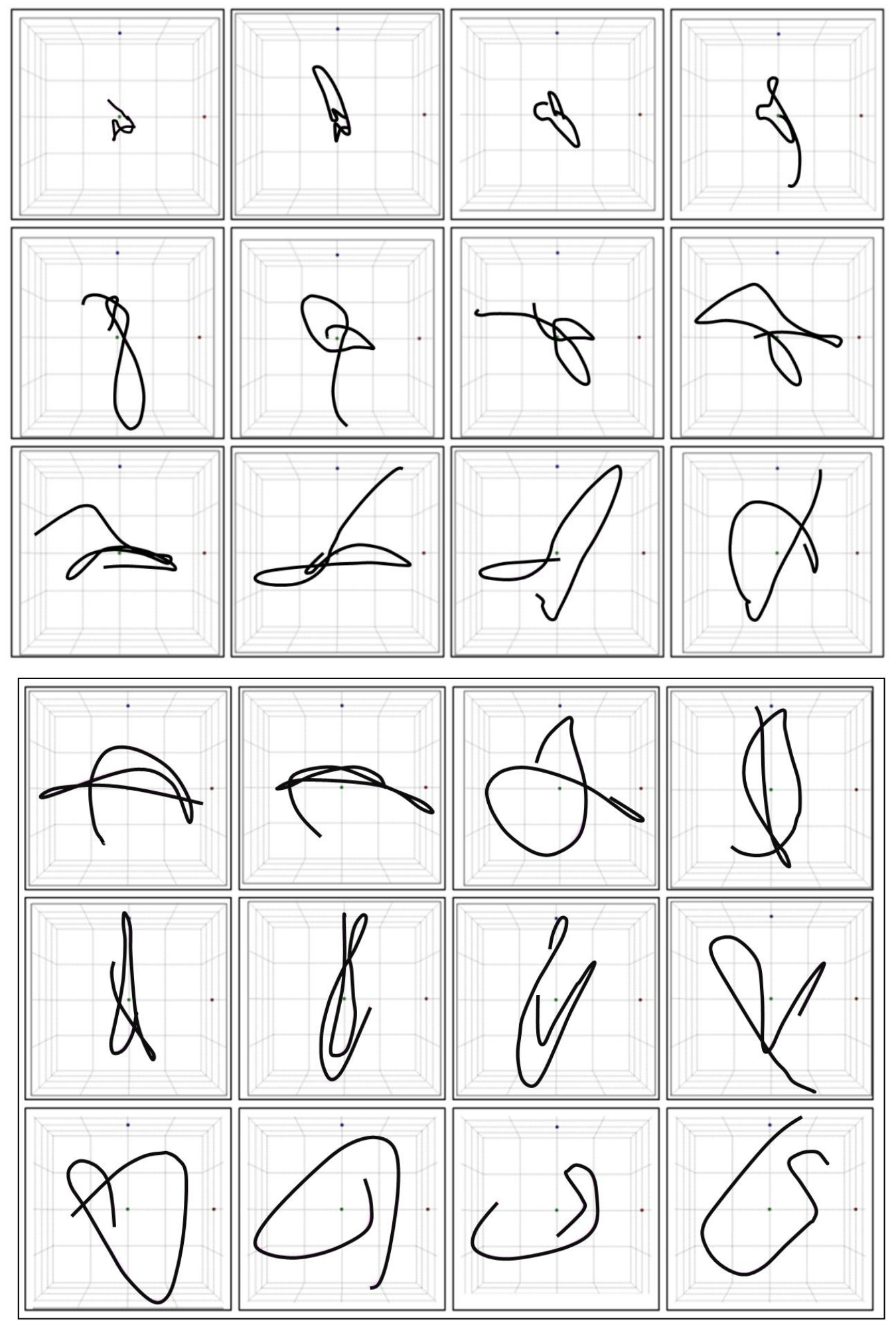

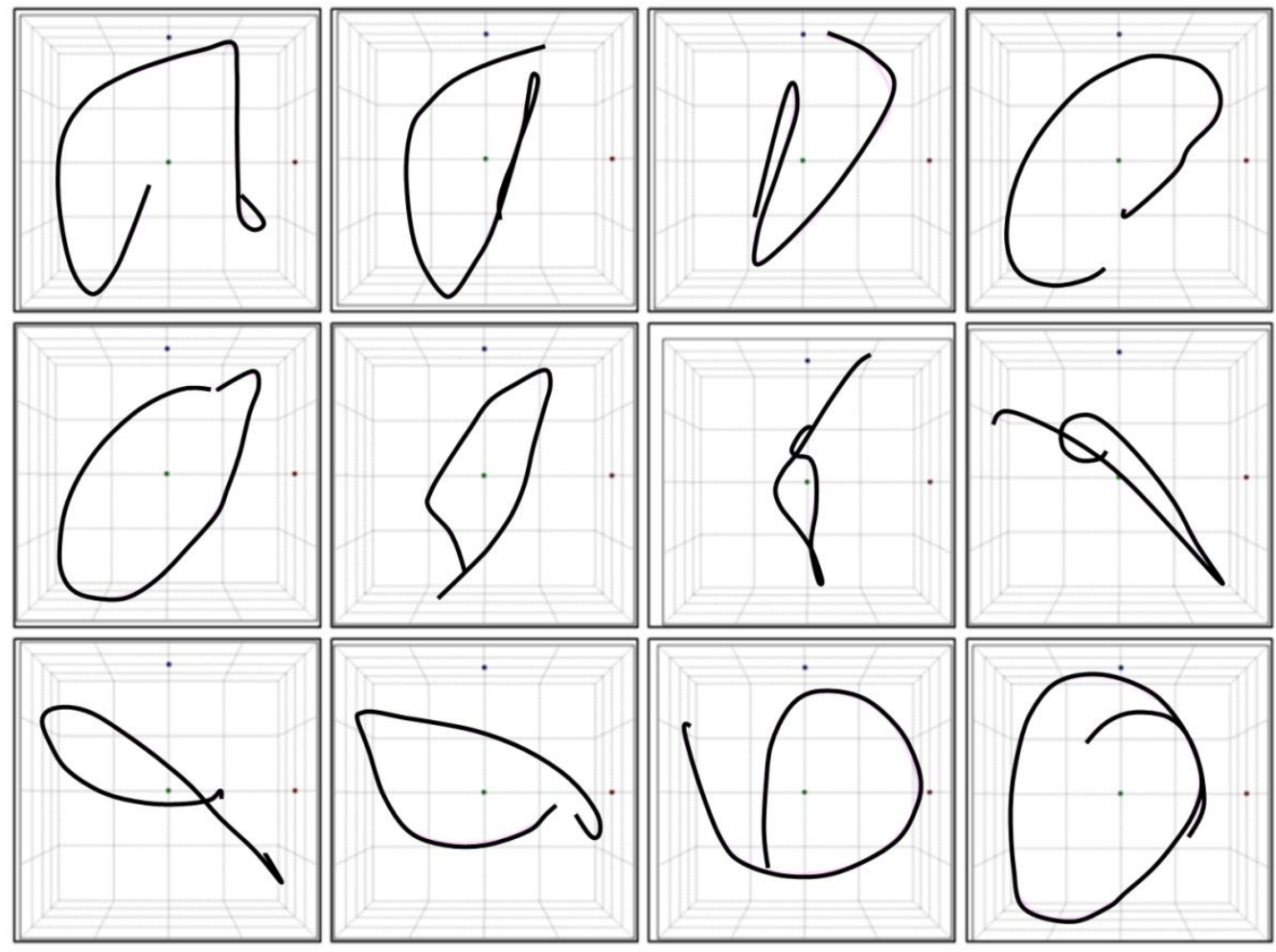

Fig. 6.Particle motion diagrams for selected seismic waves

Note that a change in the velocity of elastic body waves with direction (velocity anisotropy) leads to a change in the refraction angles, critical angles and amplitudes of transmitted waves. In addition, a change in polarization in an anisotropic medium leads to a converted particle motion for all types of body waves: P, SV, and SH. Since the depth of this earth- quake was $8 \mathrm{~km}$, and the hypocentric distance was 15 $\mathrm{km}$, we represent the waves $\mathrm{P}, \mathrm{SV}$ and $\mathrm{SH}$ as direct rays. Using the Wolf grid, we determined the incident angle and azimuth of the longitudinal and transverse seismic waves in each selected segment (Fig. 7, 8). Three main axes of a virtual polarization ellipsoid are displayed on the Wolf grid.
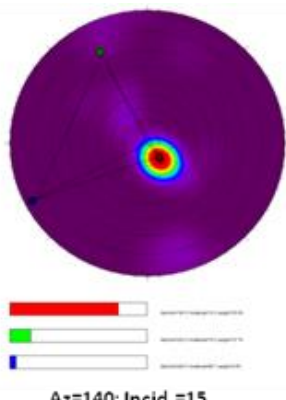

$A_{z}=140 ;$ Incid.$=15$
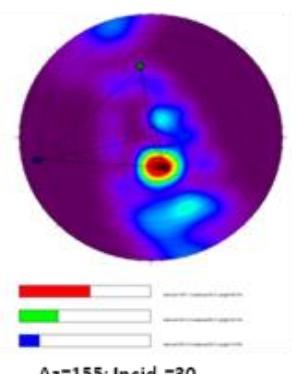

$A_{2}=155 ;$ Incid.$=30$
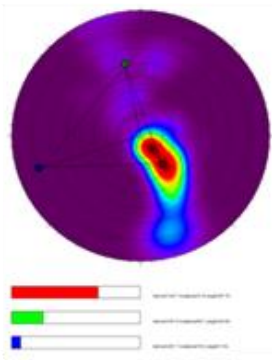

$A z=143 ;$ Incid. $=31$
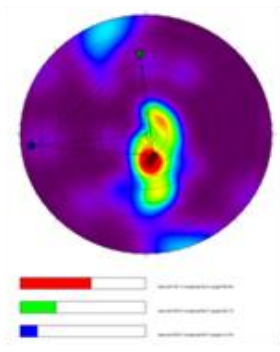

$A_{z}=161 ;$ Incid. $=22$
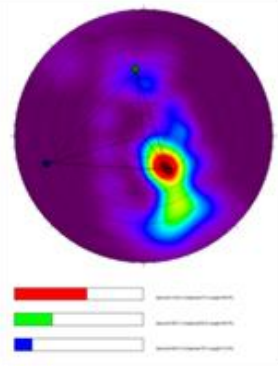

$A_{z}=144 ;$ Incid. $=37$
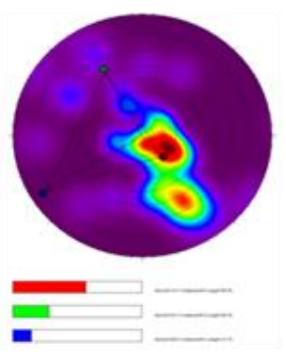

$A z=137$; Incid.$=27$

Fig. 7. An example of determining the incident angle of a longitudinal seismic wave and azimuth on the Wolf grid 

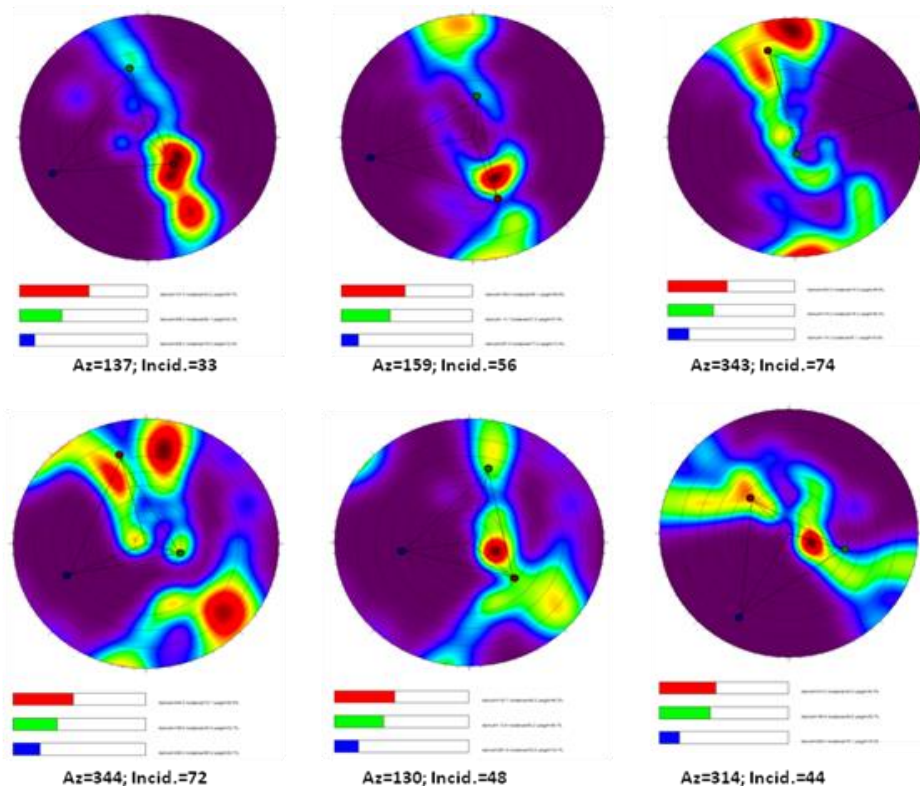

Fig. 8. An example of determining the angle of exit of a transverse seismic wave and azimuth on the Wolf grid

\section{Discussion of the results and conclusions}

Based on the obtained data, a graph of the dependence of the incident angle and azimuth of the considered seismic waves at 34 time intervals was constructed. As can be seen in the graph at the first 4 points corresponding to the longitudinal wave, the azimuth fluctuates in the range of $140-155^{\circ}$, and the incident angle $-15-37^{\circ}$. For linearly polarized oscillations, the recording form is preserved and the os- cillations are in phase, regardless of the orientation of the components in space. The nature and polarization of the longitudinal wave are independent of the source and the forces acting in it. Therefore, at each individual observation point, the nature of the polarization of wave $P$ caused by the earthquake will be the same and cannot provide information about the source.
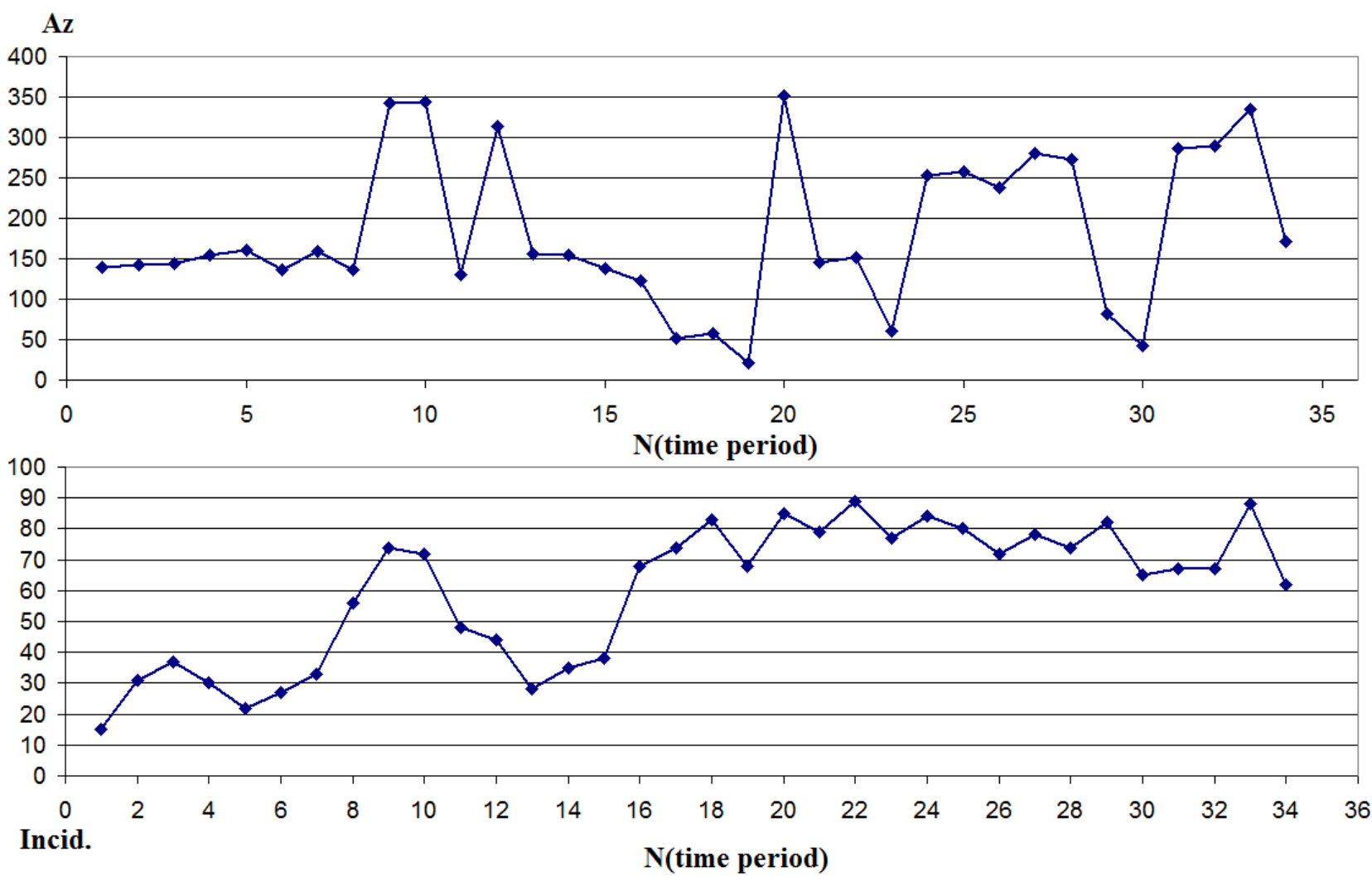

Fig. 9. Graph of the incident angle and azimuth of the considered seismic waves at 34 time intervals 
In shear waves, the action of the waves on the geophone will depend on how the geophone is oriented and in what plane, passing through the direction of wave propagation, transverse vibration occurs. In homogeneous and isotropic media, shear waves are polarized in a plane directed to the $\mathrm{P}$ wave front, i.e., the particle motion vector lies in the indicated plane and is perpendicular to the beam. Unlike a longitudinal wave, where the polarization of the oscillations is determined only by the direction of wave propagation, the polarization of the oscillations in the transverse wave depends on the type of source.

Thus, it was established that the fast and slow Swaves are well distinguished in the wave field, their polarization vectors are mutually orthogonal. Subsequent waves have much smaller amplitudes, and their azimuths are close to the azimuth of the slow wave S2. The delay time between the first and second phase of the shear wave for the ZKT station is 3 seconds with the orientation of polarization vectors along the azimuths of $140^{\circ}$ and $70^{\circ}$. As can be seen in the fig. 9, the azimuthal angle of the first shear wave (interval

\section{REFERENCES}

Galperin Y.I. Polarization method of seismic research. Nedra. Moscow, 1977, 279 p. (in Russian).

Gorshkalev S.B., Karsten V.V., Afonina E.V., Bekeshko P.S., Korsunov I.V. The results of the study of azimuthal anisotropy of the geological section in Pelyatkinskaya Square according to multi-wave VSP and 3D seismic data. Seismic Technologies, No. 3, 2011, pp. 60-70 (in Russian).

Droznin D.V., Droznina S.Y. Interactive seismic signal processing program Dimas. Kamchatka branch of the Geophysical Service of the Russian Academy of Sciences, Petropavlovsk-Kamchatsky, 2004, pp. 1-5 (in Russian).

Droznin D.V., Droznina S.Y. Interactive program for ceismic signal processing DIMAS. Seismic Instruments, Vol. 46, No. 3, 2010, pp. 22-34 (in Russian).

Luneva M.N. Temporal variations in the parameters of split Swaves from weak local earthquakes of close localization near eastern Hokkaido. Institute of Tectonics and Geophysics, Far Eastern Branch of the Russian Academy of Sciences. Physics of the Earth, No. 11, 2008, pp. 47-63.

Luneva. M.N. Seismic anisotropy and frequency dependence of wave parameters from weak earthquakes in Kuril subduction zone. Physical Mechanics, No. 12, 2009, pp. 55-62 (in Russian).

Kazimova S.E., Kazimov I.E. Seismotomographic studies of the Earth's crust of the southern slope of the Greater Caucasus. Catalog of RSSC of ANAS, 2010, pp. 82-88 (in Russian).

Kazimova S.E., Kazimov I.E. Seismic anisotropy of shear wave parameters on the example of the Hajigabul earthquake on February 10, 2014 with $\mathrm{ml}=5.8$. Geology and Geophysics of the South of Russia, No. 3, 2016, pp. 141-151 (in Russian).

Kazimov I.E., Kazimova S.E. Seismic anisotropy of rocks of the Mesocenozoic complex of the Greater Caucasus (within Azerbaijan). Proceedings ANAS, the sciences of Earth, 2011, pp. 29-34 (in Russian).

Yetirmishli G.J., Kazimov I.E. Separation of transverse wave arrivals by polarization analysis. Catalog of RSSC of ANAS, 2007, pp. 174-181 (in Russian).

https://en.wikipedia.org/wiki/Polarization_(waves)
5-8) was $130-150^{\circ}$, and the incident angle was $22-33^{\circ}$, however, in the following sections of the wave recording, the azimuthal angle sharply changes to 343$344^{\circ}$, and the incident angle - to $72-74^{\circ}$. Further, the azimuthal angle sharply changes to $130^{\circ}$, and then again moves to the fourth decade $\left(314^{\circ}\right)$.

Thus, the orientation of the forces acting in the source determines the nature of the particle motion. For a vertical axis of symmetry and sources with a horizontally acting force in the direction perpendicular to the force action, SH shear waves polarized horizontally will propagate parallel to the force. These waves are of particular interest, since when they propagate in the axis of symmetric media at the interfaces no exchange waves arise, and the wave field is relatively simple. Therefore, the $\mathrm{SH}$ method is based on the method of transverse reflected waves. It is characteristic of these waves that the direction of motion of the particles changes with changes in the direction of the forces. SV waves are polarized mainly in the vertical plane, and they, unlike SH waves, are excited by different types of sources.

\section{ЛИТЕРАТУРА}

Гальперин Е.И. Поляризационный метод сейсмических исследований. Недра. Москва, 1977, 279 с.

Горшкалев С.Б., Карстен В.В., Афонина Е.В., Бекешко П.С., Корсунов И.В. Результаты изучения азимутальной анизотропии геологического разреза на Пеляткинской площади по данным многоволнового ВСП и сейсморазведки $3 \mathrm{D}$. Технологии сейсморазведки, №. 3, 2011, с. 60-70.

Дрознин Д.В., Дрознина С.Я. Интерактивная программа обработки сейсмических сигналов Dimas. Камчатский филиал Геофизической службы РАН, ПетропавловскКамчатский, 2004, с. 1-5.

Дрознин Д.В., Дрознина С.Я. Интерактивная программа обработки сейсмических сигналов DIMAS. Сейсмические приборы, Т. 46, No. 3, 2010, с. 22-34.

Етирмишли Г.Д., Казымов И.Э. Выделение вступлений поперечных волн методом поляризационного анализа. Каталог РЦСС НАНА, 2007, с. 174-181.

Лунева М.Н. Временные вариации параметров расщепленных Sволн от слабых местных землетрясений близкой локализации под восточным Хоккайдо. Институт тектоники и геофизики ДВО РАН. Физика Земли, №. 11, 2008, с. 47-63.

Лунева М.Н. Сейсмическая анизотропия и частотная зависимость параметров волн от слабых землетрясений в Курильской зоне субдукции. Физическая механика, No.12, 2009, с. 55-62.

Казымова С.Э., Казымов И.Э. Сейсмотомографические исследования земной коры Южного склона Большого Кавказа. Azərbaycan ərazisində seysmoproqnoz müşahidəlorin kataloqu, 2010, c. 82-88.

Казымова С.Э., Казымов И.Э. Сейсмическая анизотропия параметров поперечных волн на примере Гаджигабульского землетрясения 10 февраля 2014 г. с ml=5.8. Геология и геофизика юга России, No. 3, 2016, с. 141-151.

Казымов И.Э., Казымова С.Э. Сейсмическая анизотропия пород мезокайнозойского комплекса Большого Кавказа (в пределах Азербайджана). Известия НАН Азербайджана, No. 2, 2011, с. 29-34.

https://en.wikipedia.org/wiki/Polarization_(waves) 


\title{
ПОЛЯРИЗАЦИОННЫЙ АНАЛИЗ ЗАГАТАЛЬСКОГО ЗЕМЛЕТРЯСЕНИЯ 7 МАЯ 2012 ГОДА ПО ОДНОЙ СТАНЦИИ
}

\author{
Казымова С.Э. \\ Республиканский Центр Сейсмологической Службы при НАНА \\ AZ1143, г.Баку, nросп. Г.Джавида, 123: sabina.k@mail.ru
}

\begin{abstract}
Резюме. В статье дан анализ параметров расщепленных поперечных волн от неглубокого ( $\mathrm{h}=8$ км) землетрясения, произошедшего в пределах Большого Кавказа в Загатальском районе 7 мая 2012 г. c ml=5.6. Пространственный анализ волновых форм ведется с использованием 3-х компонентных цифровых записей сигнала. Для выделенных участков 3-х компонентной записи в программе «DIMAS» строится трехмерный график траектории движения частиц и проекции траектории движения на плоскости NE, NZ, EZ. Установлен эффект двулучепреломления, т.е. поперечная волна расщепляется на две $\left(\mathrm{S}_{1}\right.$ и $\mathrm{S}_{2}$ ), каждая из которых имеет свою поляризацию и скорость для широкополосных трехкомпонентных записей (HHE, HHN, HHZ) одной сейсмической станции «ZKT». Это дало возможность изучить мелкомасштабные деформации для лучшего понимания динамических процессов и изменения свойств среды с глубиной. В то же время зависимость параметров расщепленных S-волн от направления распространения и пространственной неоднородности физических свойств среды требует более детального анализа данных в пространстве и во времени. Было установлено что быстрая и медленная S-волны хорошо выделяются в волновом поле, их векторы поляризации взаимно ортогональны. Последующие волны имеют гораздо меньшие амплитуды, и их азимуты близки к азимуту медленной волны $\mathrm{S}_{2}$. Время задержки между первой и второй фазами поперечной волны для станции ZKT составляет 3 секунды с ориентацией векторов поляризации по азимутам $140^{\circ}$ и $70^{\circ}$.
\end{abstract}

Ключевые слова: поляризация поперечных $S H$ и SV волн, фигуры Лиссажу, угол выхода и азимут сейсмических волн

\section{MAY 2012-CI İLDə BAŞ VERMIŞ ZAQATALA ZəLZəLəSININ BIR STANSIYYANIN MOLUMATLARI OSASINDA POLYARIZASIYYA TOHLILI}

\author{
Kazımova S.E. \\ AMEA nazrində Respublika Seysmoloji Xidmət Morkazi \\ AZ1143, Bakı şəh., H.Cavid prosp.123: sabina.k@mail.ru
}

Xülasə. Məqalədə 7 may 2012-ci il tarixində Böyük Qafqazın Zaqatala rayonunda baş verən, dərinliyi h=8 km, ml=5.6 olan zəlzələnin eninə dalğalarının parametrlərinin təhlili təqdim olunur. Dalğa formalarının məkan təhlili üçkomponentli rəqəmsal seysmik qeydlərindən istifadə etməklə aparılır. Dalğaların üçkomponentli rəqəmsal yazılışlarda ayrılmış sahələrin seçilməsi üçün «DIMAS» proqramında hissəciklərin hərəkətinin trayektoriyasının üçölçülü qrafikləri və NE, NZ, EZ mustəvisində hərəkətin trayektoriyasını proyeksiyası qurulmuşdur. Şuanın iki refraksiyası aşkar olunub, yəni eninə dalğaiki dalğaya bölünür ( $\mathrm{S}_{1}$ və $\mathrm{S}_{2}$ ). Hər dalğa bir seysmik stansiya üzrə öz polyarizasiyasına və üçkomponentli (HHE, HHN, HHZ) yazılışların sürətlərinə malikdir. Bu, kiçik miqyaslı deformasiyaları öyrənməyə və dərin olmayan mühitin dinamiki proseslərini və xüsusiyyətlərini daha yaxşı başa düşmək üçün imkan vermişdi. Eyni zamanda, bölünən S-dalğaların parametrlərinin mühitin fiziki xüsusiyyətlərinin yayılma istiqamətindən və məkan qeyri-bircinsliyindən asılılığı məkan və zaman məlumatlarının daha ətraflı təhlilini tələb edir. Beləliklə, sürətli birinci və ikinci eninə dalğaları dalğa sahəsində yaxşi qeyd olunur, onların polyarizasiya vektorları qarşı1ıqlı ortoqonaldır. Sonrakı dalğaların daha aşağı amplitüdaları var və onların azimutları ikinci $S_{2}$ dalğasının azimutuna yaxındır. "ZKT" stansiyası üzrə birinci və ikinci eninə dalğaların arasındakı gecikmə vaxtı 3 san, polyarizasiya vektorlarının istiqaməti $140^{\circ}$ və $70^{\circ}$ azimutları üzrədir.

Açar sözlor: SV və SH eninə dalğaların polyarizasiyası, Lissaju fiquraları, seysmik dalğaların çıxışbucă̆ və azimutu 